\title{
Erratum to: The relationship between negative life events, psychological distress and life satisfaction: a population-based study
}

Gunnvor Marum • Jocelyne Clench-Aas •

Ragnhild B. Nes • Ruth Kjærsti Raanaas

Published online: 19 February 2014

(c) Springer International Publishing Switzerland 2014

Erratum to: Qual Life Res

DOI 10.1007/s11136-013-0512-8

The original article was published with incorrect affiliation.

The author's correct affiliation is provided below.

The online version of the original article can be found under doi: 10 . 1007/s11136-013-0512-8.

G. Marum $(\bowtie) \cdot$ R. K. Raanaas

Department of Landscape Architecture and Spatial Planning, Norwegian University of Life Sciences, PB 5003, 1432 Ås,

Norway

e-mail: gunnvormarum@mac.com

J. Clench-Aas - R. B. Nes

Division of Mental Health, Norwegian Institute of Public Health,

PB 4404, Nydalen, 0403 Oslo, Norway 